\title{
廃棄物焼却施設の建設と運用に係わる環境負荷と資源量 \\ ENERGY CONSUMPTION, CARBON EMISSION AND RESOURCE CONSUMPTION DUE TO CONSTRUCTION AND OPERATION OF REFUSE-INCINERATION
}

\author{
日渡賢一*, 岡 建 雄** \\ Kenichi HIWATASHI and Tatsuo OKA
}

\begin{abstract}
This paper discribes the results of a calculation of the amount of energy consumption, carbon emission and resource consumption due to the construction and operation of refuse-incineration.In the results, we are found that the following.

(1) The final amount of energy consumption ,carbon emission and resource consumption are 469,286.8GJ, 10,385.4t-C and 48,906.2t due to the construction of refuse-incineration that can burn $360 t$ wastes for a days.

(2)The final amount of energy consumption and carbon emission are mainly related to the construction of mechanical plant and the building construction. The construction of mechanical plant account for about $70 \%$ of final energy consumption and carbon emission.

(3)The final resource consumption is mainly iron stone, limestone and gravel.The iron stone, limestone and gravel account for $28.3 \%$, $23.5 \%, 23.4 \%$ of final resource consumption due to the construction of refuse-incineration.
\end{abstract}

\section{Keywords: refuse-incineration, input/output table, Energy consumption, Carbon emission, Resource consumption} ごみ焼却施設, 産業連関表, エネルギ一使用量, 炭素排出量, 資源消費量

\section{1.はじめに}

建築物の建設に関連するエネルギー使用量と炭素排出量を 算出する研究は国内において多数報告されている。例えば、林 英明らによる地域冷暖房用の地域配管の建設を対象とした研 究 ${ }^{1)}$ 、井村秀文らによる土木工作物の建設に関する研究 ${ }^{21}$ 、住 宅3) やオフィスビル4) の建設に関する研究など多数報告され ている。これらの研究は、建設計画の段階から建設や運用に かかわる環境負荷を把握し、環境負荷の少ない計画の選定を 可能にすることを目的にしている。近年では、環境負荷の試 算を行った上で建設を行い、実際に使用した資材数量から環 境負荷を計算して試算結果を検証している報告がある5)。環境 負荷の少ない社会の害現には、建築計画や都市計画規模での 環境負荷の排出量評価を行う必要があると考える。そこで、都 市インフラの一つであり、関東地方には 325 施設ある廃棄物焼 却処理施設の建設と運用に係わる環境負荷の算定を行った。

既往の研究では、永田勝也らは廃棄物焼却施設に併設され る発電システムの有效性を評価するためにシステムの L C A 評価 を行っている。7)間宮尚らは廃棄物焼却処理施設の運用データ と廃立物の収集に関するヒアリングデータを用いて一般廃萧

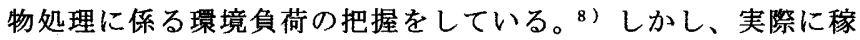
動中の廃棄物焼却施設を対象にして建設と運用に由来する環 境負荷を算出した研究はない。そこで、廃棄物処理施設の建
設と施設の運用に由来する環境負荷と使用された資源量につ いて工事種類別に調查を行ない、環境負荷と資源消費量の算 出を行なった。

\section{2. 研究硬要}

本論文では、既に稼働している廃棄物焼却施設を対象にし て建設と運用に由来する環境負荷と資源消費量を工事種類別 に算出して示した。また、併せて 1 トン当りの廃棄物焼却処 理に必要な環境負荷と資源消費量を示した。

\section{3、調查の対象}

調査を行なった廃棄物焼却施設は、平成 7 年から一般廃棄物 の焼却処理を開始した市営の施設である（表 1 ）。この廃棄物 焼却施設の最大処理能力は $360 \mathrm{t} /$ 日であり、ほほ $120 \sim 240 \mathrm{t} /$ 日の処理能力で流動的に稼働している。この施設の稼働率は 最大処理能力 $360 \mathrm{t} /$ 日で 1 年間を稼働した場合を $100 \%$ 稼働

\section{表 1 调查施設の覀要}

\begin{tabular}{|c|c|c|c|}
\hline 建築概要 & 構 造 & : & SRC造（一部RC/S造） \\
\hline & & : & 地下1階/地上6階 \\
\hline & 延べ床面積 & : & $11,000 \mathrm{~m}^{2}$ \\
\hline 設備概要 & 形 式 & $:$ & 全連続燃焼式ストーカ炬 \\
\hline & 処理能力 & $\cdot$ & $360 t /$ 日 $(120 t /$ 日 $\times 3$ 炉 $)$ \\
\hline & 余熱利用 & 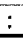 & 蒸気多一ビン発電設備 $1,600 \mathrm{~kW}$ \\
\hline
\end{tabular}

* 電源開発侏茅ヶ崎研究所 修士 (工学)

** 宇都宮大学工学部建築学科 教授・工博
Chigasaki Research Institute Electric Power Development Co., Ltd., M. Eng. Prof., Dept. of Architecture, Utsunomiya University, Dr. Eng. 
率と定義すると、約 $63 \%$ の稼働率である。また、焼却排熱を利 用する発電設備を併設し、構内電力としての利用と余剩電力 の売電を行なっている。厚生省は平成 8 年に、廃棄物焼却施設 について廃菓物処理能力を $100 \mathrm{t} /$ 日、全連続式の設備とする ガイドライン9) を示し整備することとなっている。従って、調 查対象を行なった施設の規模は今後の標淮となる規模である。 現在、人口 50 万人以上の関東地方の都市では、約 $65 \%$ の廃棄 物焼却施設が $200 \mathrm{t} /$ 日の処理能力である ${ }^{6)}$ 。

\section{4. 産萧連関分析}

極力詳細な産業部門の分類を行うために、産業連関表の原表 から直接レオンチェフ逆行列を算出した。国内の最終需要額 $Y$ より、究極的な国内総生産額 X を算出するモデル式は輸入係数 $\mathrm{m}_{i}$ を対角化した行列をM と置くと次式で表される。10）11）

$$
X=(I-(I-M) A)^{-1}((I-M) Y+E)
$$

ただし、X：究極的国内総生産額（円／年）

I : 単位行列 $(-)$

A : 投入係数 $(-)$

$\mathrm{Y}_{\mathrm{i}}, \mathrm{AE}_{\mathrm{i}}: \mathrm{i}$ 産品の国内最終需要額及び輸出額（円／年） $m_{i}: M_{i} / C_{i}(-)$

$\mathrm{M}_{\mathrm{i}} \quad: \mathrm{i}$ 産品の輸入額（円 $/$ 年）

$\mathrm{C}_{i} \quad: \mathrm{i}$ 産品の国内最終需要額に輸入額を加算し、 輸出額を差し引いた額（円／年）

レオンチェフ逆行列は（1）式の $(I-(I-M) A)^{-1}$ であり、生 産者価格基準である。商業マージンや貨物運輸・倉庫は原表 の記載データに準じると考え、相当する産業部門に振り分け た。 ${ }^{12)}$ 究極的な国内総生産額を算出するためには建設に必要 な支出を整理し、最終需要額Y として（1）式に与える。本研 究では、建設時に合わせて 1995 年の産業連関表を使用した。 ${ }^{12)}$ 計算に要した産業部門数は 397 部門である。最終需要の算出に あたっては、調査対象とした廃棄物焼却施設の建築図書等 131 を用いて工事項目毎に建設時に係る材料費と人件費（粗付加 価值）に分類した。産業連関表は生産者価格、見積書は購入 者価格で構成されているため、購入者価格から商業マージン、 運輸、倉庫費用を差引いて生産者価格に変換した。主要材料 は産業連関表に付属の物量表に記載されている金額を使用し た。経費（一般管理費）は請負金額から純工事費を差引いた 額と表され、有価証券報告書 ${ }^{14)}$ に記載されている支出割合に より動力用水費、通信費、広告宣伝費、事務用品費等を該当 する各部門に振り分けた。このように求めた材料費を最終需 要額 $\mathrm{Y}$ に相当すると考え、（1）の逆行列に投入し、廃棄物焼 却施設の建設工事による究極的な国内総生産額を求めた。ま た、産業連関表には物量表の原表が記載されており、519 の産 業業種において消費される 134 の資源や材料を物量と金額で示 している。産業連関表を用いて各業種の国内総生産額に乗じ ることにより各エ事項目でのエネルギー使用量、炭素排出量、 資源消費量を算出した。この手法の特徴は産業連関分析によ り平均値として単位購入額当りのエネルギー使用量、炭素排出 量、資源消費量を正確に求めることがができる。ただし、エネ
ルギー使用量、炭素排出量、資源消費量が価格に正比例する ことが前提条件として産出されている。また、本論文では海 外波及効果分は計算結果に含めていないが固定資産形成分は 計算結果に含めている。

\section{表 2 主要資材の使用量（建筑・建筑設㔂エ事）}

\begin{tabular}{|c|c|c|c|c|c|}
\hline 工事名 & 䬭材 & 工禹種頪 & 数量小計 & 数量合計 & 单位 \\
\hline \multirow[t]{35}{*}{ 建策工事 } & 是場 & 仮設工事 & & 54,635 & $\mathrm{~m}^{2}$ \\
\hline & 根切·掘削 & 土工事 & & 30,245 & $\mathrm{~m}^{3}$ \\
\hline & 残士処分 & 土工事 & & 30,245 & $\mathrm{~m}^{3}$ \\
\hline & 埋宊 & 土工事 & & 6,351 & $\mathrm{~m}^{3}$ \\
\hline & 碎石地幕 & 土工事 & & 747 & $\mathrm{~m}^{3}$ \\
\hline & \multirow{2}{*}{ 鎙材/デッキプレート } & 土工事 (山留) & 1,031 & 1,992 & $t$ \\
\hline & & 鉄骨工事 & 961 & & $t$ \\
\hline & \multirow{2}{*}{ 鈇能 } & 珫地業工事 & 145 & 1,188 & $\mathrm{t}$ \\
\hline & & 铁備工事 & 1,043 & & $t$ \\
\hline & \multirow[t]{2}{*}{ コンクリート } & 杭地業工事 & 20 & 8,680 & $\mathrm{~m}^{3}$ \\
\hline & & コンクリート工事 & 8,660 & & $\mathrm{~m}^{3}$ \\
\hline & 型枠（普通／打放） & 型椎工事 & & 49,710 & $\mathrm{~m}^{2}$ \\
\hline & 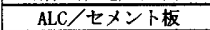 & 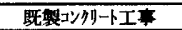 & & 8,952 & $\mathrm{~m}^{2}$ \\
\hline & \multirow[t]{2}{*}{ モルタル吹付け／塗り } & 土工事 & 770 & 65,807 & $\mathrm{~m}^{2}$ \\
\hline & & 左官工事 & 65,037 & & $\mathrm{~m}^{2}$ \\
\hline & $\begin{array}{c}\text { 防水(アスファルト/吐 } \\
\text { 獏/モルタル }\end{array}$ & 防水工事 & & 6,191 & $\mathrm{~m}^{2}$ \\
\hline & コーキンク & 防水工事 & & 4,933 & $\mathrm{~m}$ \\
\hline & 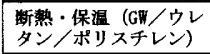 & 内装工事 & & 8,530 & $\mathbf{m}^{2}$ \\
\hline & \multirow{3}{*}{ 吐 装 } & 秐装工事 & 24,120 & 40,546 & $\mathrm{~m}^{2}$ \\
\hline & & 鉄骨工事 & 12,507 & & $\mathrm{~m}^{2}$ \\
\hline & & 左官工事 & 3,919 & & $\mathrm{~m}^{2}$ \\
\hline & プラスターボード & 内装工事 & & 8,018 & $\mathrm{~m}^{2}$ \\
\hline & 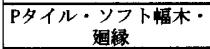 & 内装工事 & & 4,235 & $\mathrm{~m}^{2}$ \\
\hline & \multirow{4}{*}{\begin{tabular}{|c|} 
アルミ笠木 \\
ヌーナーアンクル \\
鞋鉄下地 \\
手摺り \\
\end{tabular}} & 金属工事 & & 1,367 & $\mathbf{m}$ \\
\hline & & 金属工事 & & 1,163 & $\mathbf{m}$ \\
\hline & & 金属工事 & & 3,782 & $\mathrm{~m}^{2}$ \\
\hline & & 金属工事 & & 523 & $\mathbf{m}$ \\
\hline & $\begin{array}{c}\text { アルミ/SUS建具/シャッ } \\
\text { ター/スチール/木製 }\end{array}$ & 建具工事 & & 911 & $\mathrm{~m}^{2}$ \\
\hline & ガラス工事 & ガラス & & 514 & $\mathrm{~m}^{2}$ \\
\hline & グラウト & 杭地業工事 & & 53 & $\mathrm{~m}^{3}$ \\
\hline & 幣 油 & 土工事 & 179,569 & 202,203 & I \\
\hline & & 杭地羓工事 & 19,602 & & 1 \\
\hline & & コンクリートエ事 & 3,032 & & 1 \\
\hline & 重 油 & 左官工事 & 8,811 & 326,798 & 1 \\
\hline & & 防水工事 & 317,987 & & 1 \\
\hline 給排水衞生 & 受水・高架水檩 & 給水設偏工撃 & & 2 & 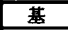 \\
\hline 設備工事 & 配管類 & 給水設麻工事 & 1,754 & 5,858 & $\mathbf{m}$ \\
\hline & & 給湯工事 & 1,142 & & $\mathbf{m}$ \\
\hline & & 排水設橵工事 & 1,695 & & $\mathbf{m}$ \\
\hline & & ガス設储工事 & 457 & & $\mathbf{m}$ \\
\hline & & 屋内消火栓 & 810 & & $\mathbf{m}$ \\
\hline & 給湯装䁬 & 給湯工事 & & 1 & 台 \\
\hline & ポンプ & 排水設供工事 & 8 & 10 & 台 \\
\hline & & 屋内消火拴工事 & 2 & & 台 \\
\hline & 第生器具 & 䈑生器真工事 & & 83 & 器 \\
\hline & 厔内消火栓 & 屋内消火栓 & & 24 & 台 \\
\hline 空禍破備工事 & FAN & 空徟機器工事 & & 53 & 台 \\
\hline & & 換気機器設傅工重 & & 114 & 台 \\
\hline & パケージ空雨 & 空㐮機器工事 & & 10 & 台 \\
\hline & 配管類 & 空珷配管工事 & & 2,286 & 뚀 \\
\hline & バルフ & 空調配管工事 & & 107 & 熎斥 \\
\hline & タク卜 & 空堣ダクト設满工事 & 711 & 6,365 & $\mathrm{~m}^{2}$ \\
\hline & & 塖気機器設俌工事 & 5,478 & & $\mathrm{~m}^{2}$ \\
\hline & & 機械排煌工事 & 176 & & $\mathrm{~m}^{2}$ \\
\hline & スパイラルダクト & 空訊ダクト設偏工事 & 161 & 444 & $\mathbf{m}$ \\
\hline & & 換気機器設满工事 & 283 & & $\mathrm{~m}$ \\
\hline & 排煙口 & 機械排㛐工事 & 5 & 5 & 圈 \\
\hline 龟気設僧工事 & 動力/分電整 & 幹線設健工事 & 37 & 41 & 面 \\
\hline & & 動力設備工事 & 4 & & 面 \\
\hline & 操作盤 & 電灯設偏工事 & 22 & 51 & 面 \\
\hline & & 電話設䏴工事 & 7 & & 面 \\
\hline & & 火㷋報知設漕 & 22 & & 面 \\
\hline & ケーフル/配線 & 幹線設健工事 & 6,523 & 55,786 & $\mathbf{m}$ \\
\hline & & 的力設備工事 & 10,861 & & $\mathbf{m}$ \\
\hline & & 電灯設健工事 & 33,966 & & $\mathbf{m}$ \\
\hline & & 火织報知設诺工事 & 4,436 & & $\mathrm{~m}$ \\
\hline & ケーフルラック & $\begin{array}{l}\text { 幹線設借工事 } \\
\end{array}$ & 207 & 207 & 国 \\
\hline & 電線管 & コンセント工事 & 7,441 & 11,252 & 本 \\
\hline & & 火㷋報知設哄工事 & 3,810 & & m \\
\hline & IVピニール黾線 & コンセントエ事 & & 7,657 & $m$ \\
\hline & 裹灯/水銀灯 & 電灯設供工事 & & 1,507 & 重 \\
\hline & 時胡 & 龟気帱計工事 & & 34 & 因 \\
\hline & インターフォン & インターフォン設傮 & & 41 & 台 \\
\hline & 㷮感知器 & 火㷋報知設偏工事 & & 336 & 曾 \\
\hline & 空気管 & 火災報知設備工事 & & 2,100 & $m$ \\
\hline & ハンドホール & 栗内配電線路工事 & & 9 & 基 \\
\hline & 外灯 & 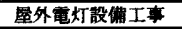 & & 15 & 圈 \\
\hline & ELV & 界降機設備工事 & & 2 & 台 \\
\hline
\end{tabular}


表 3 主要费材使用

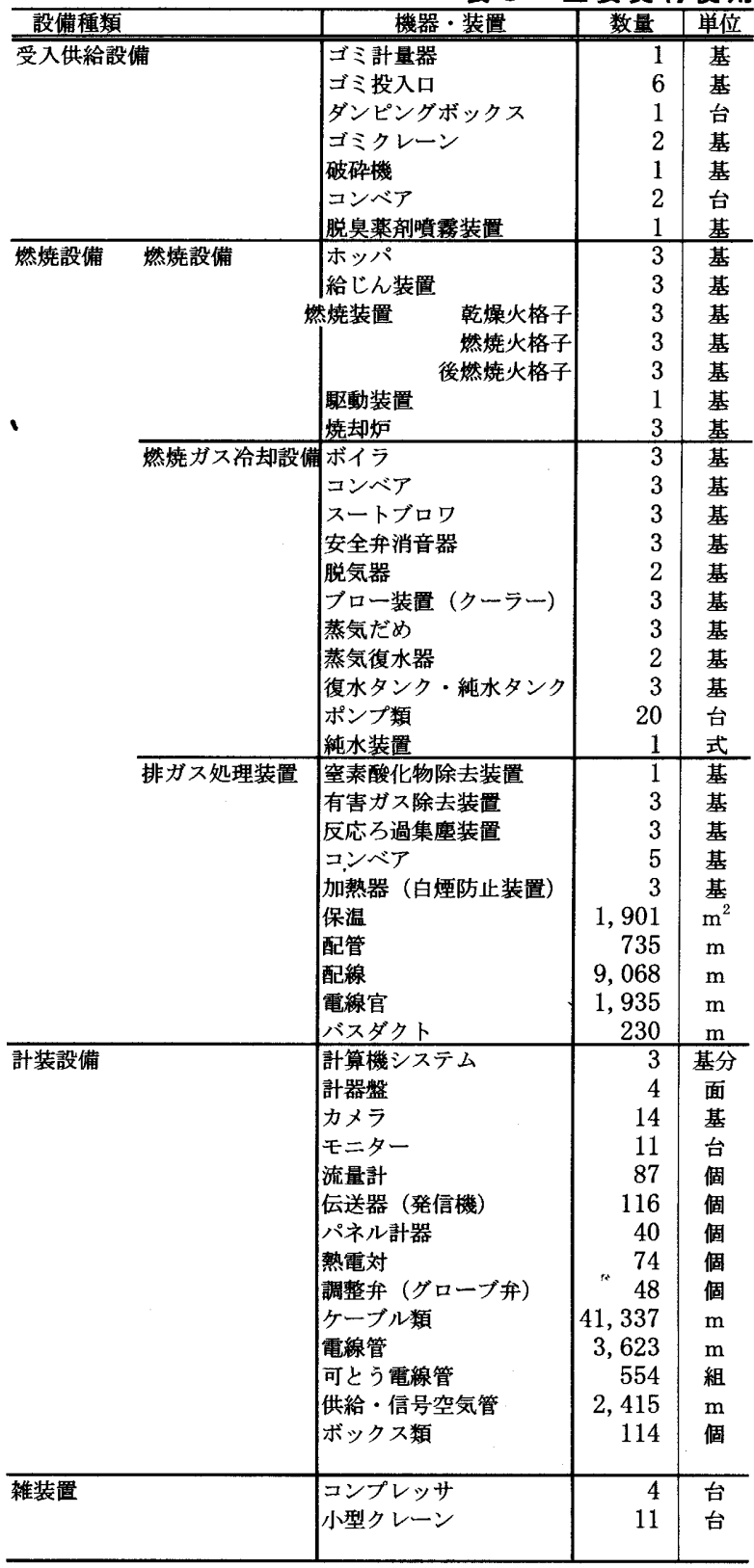

\section{5. 資料集部方法}

廃棄物焼却施設の建設工事は建築工事と廃棄物処理プラン 卜機械工事が混在しており、建築工事とプラント機械工事の 工事金額はほぼ同等である ${ }^{13)}$ 。建築工事は、工事契約書に使用 資材毎に工事数量が記載されているものの、プラント機械は 複数の装置や小型機器から構成されており、構成要素につい て一式価格で記載されているために使用資材や数量について 詳細な情報を得ることは難しい。そこで、機械の構成装置ご とに分けて上記の方法で産業連関分析を行ない、環境負荷の 算定を行なった。また、併わせて横山らが開発した究極的な 資源消費量の算定方法を用いて資源消費量を算定した。 ${ }^{15}$ ) 表 2 には廃棄物焼却施設の建設工事を建築工事と建築設備工事 に分け、使用された主要な資材と主要な機器・装置を工事種 類別に示した。表 3 にはプラント機械工事に使用された機器・ 装置や資材を廃棄物処理プラントを構成する設備別に示した。 また、工事契約書に機器価格等が一式単価として計上されて
(プラント椺柱事)

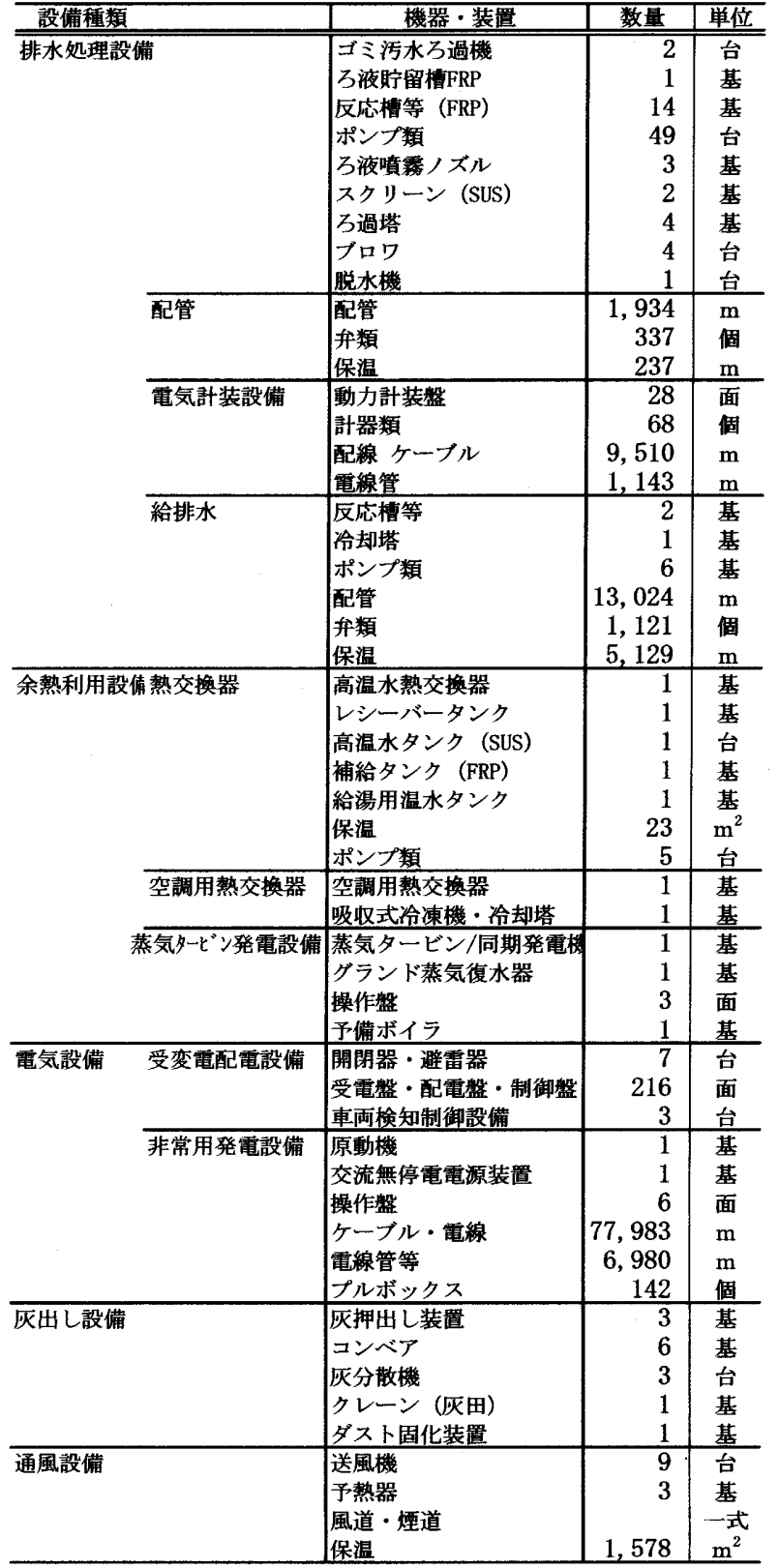

いる項目については、積算資料16１7１8１9１9やメーカーヒアリン グを行ない分類した。機器・装置や資材の分類は産業連関表中 の項目別に行い、一式計上されている機械費は工事に使用さ れる重機械の償却及び管理に必要な对価と考えて集計した。

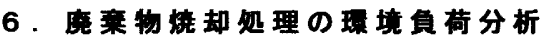

\section{1 建設エ事の物兵}

建築工事に使用された資材量を表 2 に示した。これらの資 材量は契約書からほぼ全ての使用資材量を定量化することが 可能である。例えば、代表的な建築資材である鉄骨、生コン クリート、鉄笳はそれぞれ $1,992 \mathrm{t} 、 8,680 \mathrm{~m}^{3} 、 1,188 \mathrm{t}$ であり、 廃棄物焼却施設の建設工事に由来する単位床面積当りの使用 量はそれぞれ $181 \mathrm{~kg} / \mathrm{m}^{2} 、 0.79 \mathrm{~m}^{3} / \mathrm{m}^{2} 、 108 \mathrm{~kg} / \mathrm{m}^{2}$ である。特に、土 工事において鉄骨の使用量が多い。これは、土工事に执いて ソイルセメント連続壁工法注1) を採用しており、山留め工事の 擁壁の芯にH 型鋼使用していることに起因している。建築工事 
は表 2 に示したように資材の使用量を契約書等から算出する ことが可能である。しかし、プラント機械工事は、契約書に 設備を構成する資材や装置の台数と価格で記載され、装置構 成部材の素材数量を全て推定することは難しい。プラント機 械工事の工事費の大部分を占めるボイラ、焼却炬、燃焼装置 は契約書において鉄骨重量や設備を構成する機器と装置の価 格で記載されることから、建築工事のように設備製作のため の資材消費量を契約書から詳細に求めることはできない。そ こで、次節 6.2 に示す方法で資源消費量を求めた。

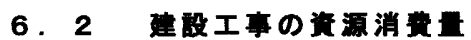

横山計三らの研究 $^{15}$ ) では、産業連関表を用いて各産業に百 万円の資本が投入された場合に、その産業分野での資源消費 量の算出が可能な方法を提案している。横山計三らの研究で 提案している手法は各産業分野ごとに資源消費量や基碄 2 次 製品消費量の波及効果を含めた重量を求められることが特徵 である。この手法を用いて基礎 2 次製品の波及効果を含む資 源消費量を計算した。ここでの基礎 2 次製品とはゴム、合成 樹脂、特殊鋼、銅、アルミとした。その計算結果と対象機械 のメーカーヒアリング重量を比較し、計算結果の妥当性を検 証した。表 4 には、計算から求めた代表的なプラント機械の 基礎 2 次製品総重量と対象機械の重量のヒアリング結果を示し た。また、表 4 に示した機械重量を横軸に、メーカーヒアリ ング及びカタログから求めた機器重量を縦軸にとり、両者の 関係を図 1 に示した。両者は相関係数 0.96 の関倸となる。近 似式で表現すると、計算から求めた基礎 2 次製品総重量の約 66 \%がメーカーヒアリングによる機械重量となる。この結果か らこの計算手法を廃棄物焼却施設の資源消費量算出への適用 が可能であると考え、この手法を用いて資源消費量を計算し て表 5 に示した。資源消費量は、木材、鉄鉱石、銅・アルミニウム、 石灰石、砂利 - 碎石 - 石材、石炭、原油、天然ガス、天然緎 維・農産物の 8 種類について計算した。これらの資源は建設業 で多く用いられる木材製品、鉄鋼製品、セメント、コンクリー 卜、エネルギー、化学製品、緘維製品の原料となる資源であ る。これらの資源消費量を建築工事、建築設備工事、プラン 卜機械工事、共通仮設・開接費に分けて集計した。さらに、建 築工事は表 5 中の 21 の工事種類別に分類し、建築設備工事に ついても給排水衛生設備、空調設備、電気設備に分けて分類 した。また、プラント機械工事は、廃棄物焼却プラントを構 成する主要な受入供給設備、焼却設備、灰出し設備、通風設 備、排水処理設備、余熱利用設備、電気設備、計装設備、雑装

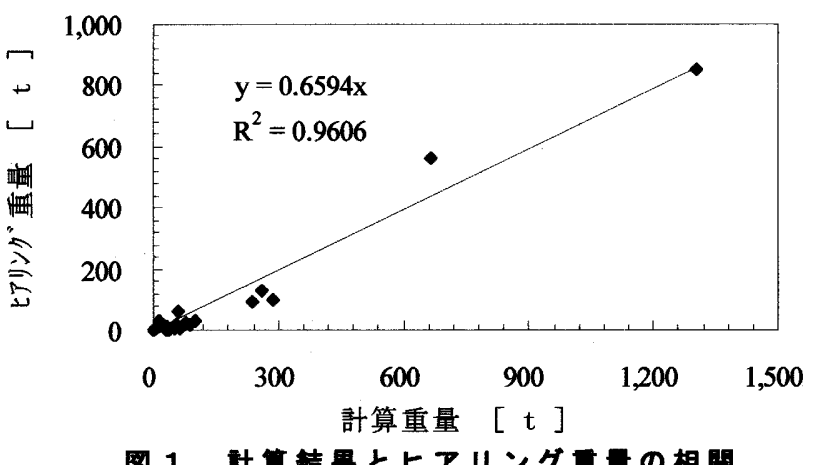

图 1 計苝結果とヒアリング量鼻の相閶
置の 9 設備に分類して表 5 に記した。表中のマイナス（A）の 数字は、その産業の需要によって副産物や屑として直接又は 間接的に産出されるものを表している。例えば、「砂利・砕石・ 石材」は、鉄鋼の生産プロセスで副産物（スラグ）として産出 されるので、鉄の需要が大量にある部門ではマイナスとなる。 表 6 中のハッチング部分は、建築工事、建築設備工事、プラ ント機械工事、共通仮設工事それぞれの資源消費量の合計を 示した。また、工事に使用した資源（木材、鉄鋼石、銅・ア ルミニウム、石灰石、砂利等、石炭、原油、天然ガス、天然 織維・農産物）のそれぞれが占める割合を示している。また、 最下段に廃棄物焼却施設の建設工事において消費された資源 量の総量 $(48,906.2 \mathrm{t})$ とその資源別の重量と割合を示した。 表 5 の計算結果をもとに建築工事に限定して資源消費の割合 を比較すると砂利等は副産物による差引き分を考慮すると $7,966.6 \mathrm{t}$ が使用され、資源消費量の $33.6 \%$ 占めている。石灰 石の使用量は $6,675.6 \mathrm{t}$ であり、資源消費量の $28.1 \%$ 占めてい る。鉄鋼石の使用量は $5,585.7 \mathrm{t}$ であり、資源消費量の $23.5 \%$ を占めている。プラント機械工事に限定して資源消費の割合 を比較すると、鉄鋼石の使用量は $7,773.8 \mathrm{t}$ であり、資源消費 量の $34.3 \%$ を占めている。石灰石の使用量は $4,434.1 \mathrm{t}$ であり、 資源消費量の $19.6 \%$ を占めている。石炭の使用量は $3,861.7 \mathrm{t}$ であり、資源消費量の $17.1 \%$ を占めている。また、工事種類 別の資源消費の割合を計算し図 2 に示した。工事種類別の資 源消費重量の割合は建築工事が $48.5 \%$ 、建築設備工事が $2.1 \%$ 、 プラント機械工事が $46.3 \%$ 、共通仮設等が $3.1 \%$ である。全体 の資源消費量の約 $95 \%$ は建築工事とプラント機械工事に由来 する資源である。次に、建設工事に使用された資源種類別の 消費割合を図 3 に示した。資源別の消費割合は鉄鋼石が $28.3 \%$ 、石灰石が $23.5 \%$ 、砂利等が $23.4 \%$ 、石炭が $13.7 \%$ 、原油 が $8.4 \%$ 、天然ガスが $1.4 \%$ 、木材が $0.9 \%$ 、銅・アルミが $0.7 \%$ 、 絾維・農産物等が $0.1 \%$ である。廃棄物焼却施設工事全体では 鉄鉙石の使用量が最も多く、建築工事に関しては、砂利類の 消費量が最も多い。廃裹物焼却施設の建設に由来する単位床 面積当りの資源消費量は $4.4 \mathrm{t} / \mathrm{m}^{2}$ であり、内訳は建築工事が $2.1 \mathrm{t} / \mathrm{m}^{2}$ 、建築設備工事が $0.1 \mathrm{t} / \mathrm{m}^{2} 、$ プラント機械工事が $2.1 \mathrm{t} /$ $\mathrm{m}^{2}$ 、共通仮設等が $0.1 \mathrm{t} / \mathrm{m}^{2}$ である。なお、単位床面積当りの 資源消費量は、資源消費量の総量を延べ床面積 $11,000 \mathrm{~m}^{2}$ で除 して求めた。

\section{3望設エ事の桭境負荷}

横山謙司らの研究 ${ }^{201}$ では産業連関表を用いて、各産業に百 万円の資本が投入された場合に、その産業分野で発生する環 境負荷の算出方法を提案している。横山謙司らの研究で提案 している手法では百万円の資本投入による波及効果も含めた 環境負荷を求めることができる。この手法を用いて廃棄物焼 却施設の建設に由来する環境負荷の算出を行い表 6 に示した。 表 6 には環境負荷を建築工事、建築設備工事、プラント機械 工事、共通仮設・間接費に分けて集計した。さらに、建築工 事は表 6 に示した 21 の工事種類別に分類し、建築設備工事に ついても給排水衛生設備、空調設備、電気設備に分けて分類 した。また、プラント機械工事は、廃棄物焼却プラントを構 
表 4 計算轺果と対象機器のメーカーヒアリング重且の比较

\begin{tabular}{|c|c|c|c|c|c|c|c|c|c|c|}
\hline \multirow{2}{*}{ 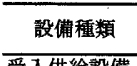 } & \multirow{2}{*}{\multicolumn{3}{|c|}{ 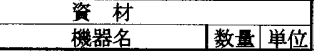 }} & \multirow{2}{*}{\multicolumn{5}{|c|}{ 基礎 2资製品资材重量 $[t]$}} & \multirow{2}{*}{\multicolumn{2}{|c|}{ 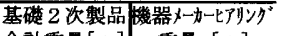 }} \\
\hline & & & & & 合成樹脂 & & & $\overline{P ル:}$ & 合計重量 $[t]$ & \\
\hline \multirow[t]{3}{*}{ 受入供給設備 } & ゴミクレーン & 2 & 基 & 2.7 & 9.7 & 255.7 & 5.2 & 12.0 & 285.3 & 100.0 \\
\hline & 破硦機 & 1 & 基 & 1.2 & 1.3 & 47.6 & 0.2 & 3.0 & 53.3 & 16.0 \\
\hline & 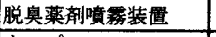 & & 基 & 0.1 & 0.4 & 7.2 & 0.1 & 0.6 & 8.4 & 10.0 \\
\hline \multirow[t]{14}{*}{ 然燒設僱 } & ホッパ & 3 & 基 & 0.1 & 0.6 & 11.7 & 0.1 & 0.9 & 13.4 & $\overline{30.0}$ \\
\hline & $\begin{array}{l}\text { 給じん装置 } \\
\text { 然焼装圈 }\end{array}$ & 3 & 基 & 0.5 & 2.4 & 44.4 & 0.5 & 3.6 & 51.4 & 15.0 \\
\hline & 乾燥火格子 & 3 & 基 & 0.3 & 2.5 & 90.2 & 0.5 & 6.7 & 100.2 & 33.0 \\
\hline & 燃燒火格子 & 3 & 基 & 0.8 & 6.4 & 234.4 & 1.4 & 17.5 & 260.5 & 132.0 \\
\hline & 後燃燒火格子 & 3 & 基 & 0.2 & 1.9 & 69.1 & 0.4 & 5.2 & 76.8 & 22.0 \\
\hline & 焼却炉 & 3 & 基 & 0.1 & 0.8 & $1,300.1$ & 0.1 & 1.5 & $1,302.6$ & 849.0 \\
\hline & 落锂ホッパシュート| & 3 & 基 & 0.0 & 0.2 & 6.7 & 0.0 & 0.5 & 7.4 & 15.0 \\
\hline & ボイラ & 3 & 基 & 1.0 & 10.0 & 627.8 & 8.8 & 19.6 & 667.2 & 559.0 \\
\hline & 高圧蒸気復水器 & 1 & 基 & 0.3 & 1.3 & 23.7 & 0.3 & 1.9 & 27.5 & 8.0 \\
\hline & 低圧蒸気復水器 & 1 & 基 & 0.3 & 1.5 & 27.1 & 0.3 & 2.2 & 31.4 & 10.0 \\
\hline & 復水タンク & 2 & 基 & 0.0 & 0.2 & 3.4 & 0.0 & 0.3 & 3.9 & 6.8 \\
\hline & 純水タンク & 1 & 基 & 0.0 & 0.0 & 0.9 & 0.0 & 0.1 & 1.0 & 0.4 \\
\hline & 反応万過集豦装亶 & 3 & 基 & 2.4 & 11.1 & 204.6 & 2.2 & 16.5 & 236.8 & 90.0 \\
\hline & 加熱器（白煙防止装圈 & 3 & 基 & 0.7 & 3.0 & 54.6 & 0.6 & 4.4 & 63.3 & 6.0 \\
\hline \multirow[t]{3}{*}{ 灰出し設備 } & 灰押出し装置 & 3 & 基 & 0.5 & 1.7 & 45.5 & 0.9 & 2.1 & 50.7 & $\frac{6.0}{6.0}+(x)$ \\
\hline & コンベア & 6 & 基 & 0.6 & 2.0 & 53.2 & 1.1 & 2.5 & 59.4 & 60.0 \\
\hline & クレーン（兏田用） & 1 & 基 & 0.8 & 3.0 & 78.3 & 1.6 & 3.7 & 87.4 & 18.0 \\
\hline \multirow[t]{5}{*}{ 排水处理設備 } & $\exists$ ヨ゙ミ污水万過機 & 2 & 台 & 0.0 & 0.0 & 0.9 & 0.0 & 0.1 & 1.0 & $\overline{2.0}$ \\
\hline & 万液眝留槽 & 1 & 基 & 0.0 & 0.0 & 0.4 & 0.0 & 0.0 & 0.4 & 0.1 \\
\hline & 反応槽等 & 13 & 基 & 0.4 & 1.7 & 30.6 & 0.3 & 2.5 & 35.5 & 1.3 \\
\hline & 万過塔 & 2 & 基 & 0.1 & 0.6 & 11.2 & 0.1 & 0.9 & 12.9 & 10.0 \\
\hline & 脱水機 & 1 & 台 & 0.3 & 1.2 & 22.4 & 0.2 & 1.8 & 25.9 & 11.0 \\
\hline \multirow[t]{2}{*}{ 余繁利用設備 } & 蒸気タービン & 1 & 基 & 0.1 & 0.5 & 30.0 & 0.6 & 1.5 & 32.7 & $\overline{1.3}$ \\
\hline & 同期発電機 & 1 & 基 & 0.1 & 1.1 & 23.4 & 1.1 & 2.9 & 28.6 & 13.0 \\
\hline
\end{tabular}

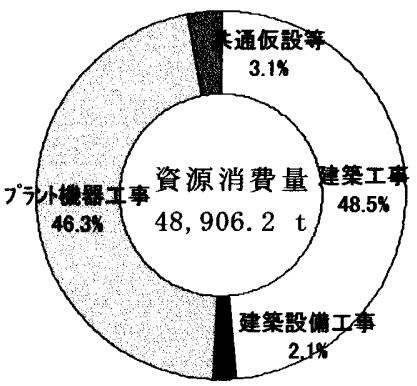

國 2 资源消费且のエ事別宫合

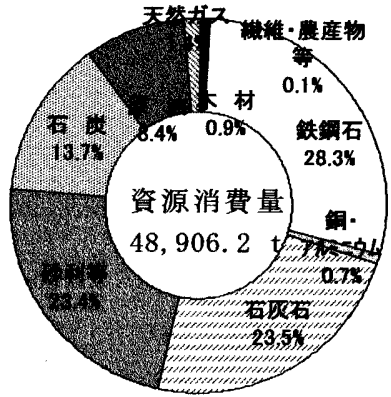

表 5 究㗏的な算源消费

图 3 資源消费量の资洒別害合

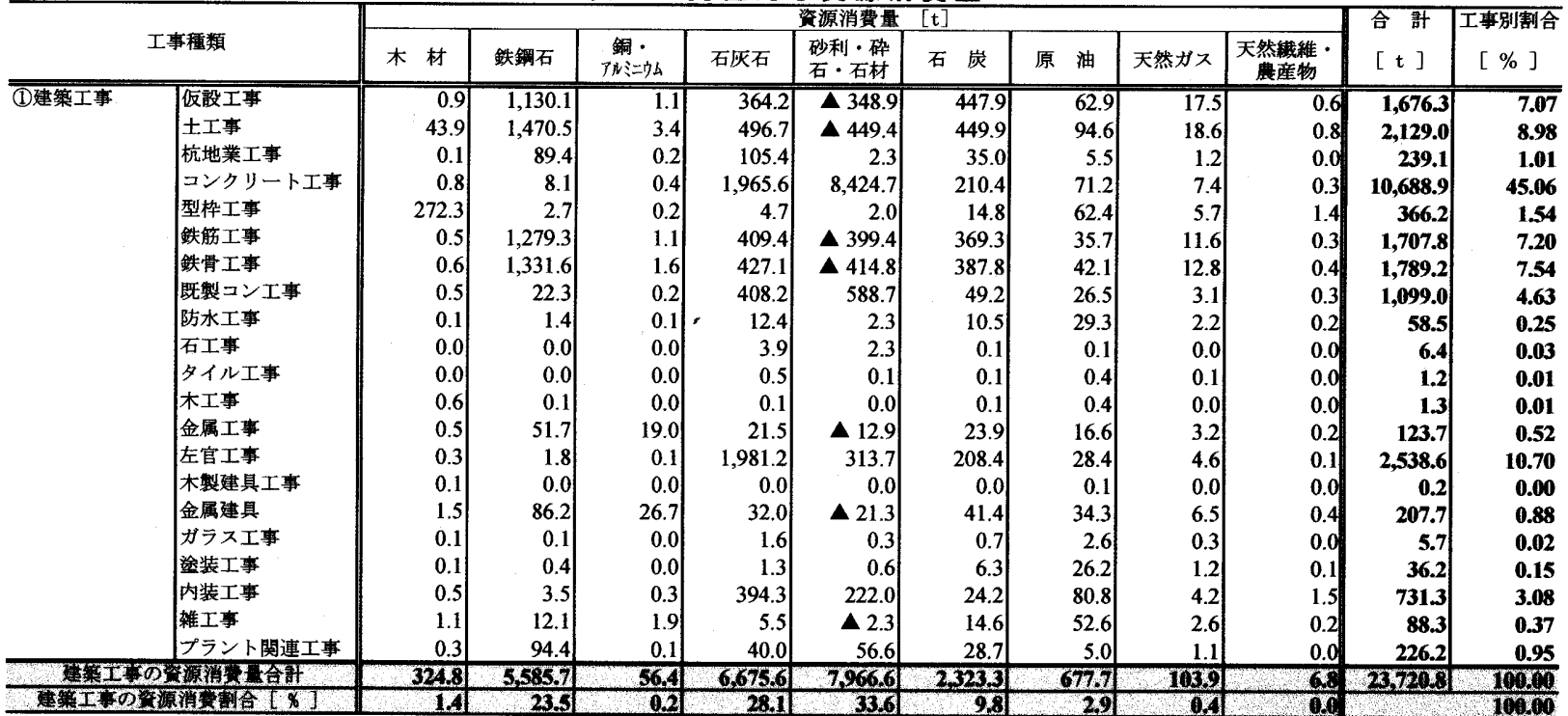

\begin{tabular}{|c|c|c|c|c|c|c|c|c|c|c|c|c|}
\hline (2)建築設伴工事 & $\begin{array}{l}\text { 給排水衛生設㒉 } \\
\text { 空調設偏工事 } \\
\text { 電気設備工事 }\end{array}$ & $\begin{array}{l}0.4 \\
0.7 \\
3.1 \\
\end{array}$ & $\begin{array}{r}70.0 \\
234.6 \\
92.9 \\
\end{array}$ & \begin{tabular}{r|}
1.3 \\
2.9 \\
19.0 \\
\end{tabular} & \begin{tabular}{r|}
45.9 \\
124.4 \\
55.2 \\
\end{tabular} & $\begin{array}{r}\mathbf{\Delta} 5.4 \\
\mathbf{4} 42.9 \\
3.7 \\
\end{array}$ & $\begin{array}{l}35.2 \\
87.7 \\
72.5 \\
\end{array}$ & \begin{tabular}{r|}
30.5 \\
43.1 \\
113.4 \\
\end{tabular} & \begin{tabular}{r|}
3.1 \\
6.5 \\
16.8 \\
\end{tabular} & $\begin{array}{l}0.1 \\
0.4 \\
1.1 \\
\end{array}$ & $\begin{array}{l}181.1 \\
457.4 \\
377.6 \\
\end{array}$ & $\begin{array}{l}17.83 \\
45.01 \\
37.16 \\
\end{array}$ \\
\hline \multicolumn{2}{|c|}{ 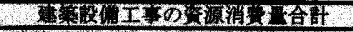 } & 32 & 3थs & 23.2 & 225.5 & $\triangle 446$ & 198. & 1870 & 26,1 & 176 & Tors & Whan \\
\hline \multicolumn{2}{|c|}{ 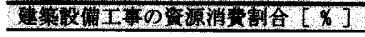 } & 0.4 & 39.1 & 23 & 22.2 & $\mathbf{4 . 4}$ & 19.2 & 18.4 & 26 & a2 & & 1000 \\
\hline \multirow[t]{9}{*}{ (3)プ ラント機栰工事 } & 受入供給設備 & 20.5 & $1,034.0$ & 36.9 & $1,108.1$ & $2,853.2$ & 541.2 & 348.4 & 56.7 & 3.6 & $6,002.6$ & 26.52 \\
\hline & 燃焼設備 & 36.5 & $3,437.9$ & 119.8 & $1,646.9$ & $\Delta \mathbf{6 7 5 . 0}$ & $1,808.1$ & $1,554.4$ & 253.2 & 15.3 & $\mathbf{8 , 1 9 7 . 3}$ & 36.21 \\
\hline & 灰出し設備 & 10.8 & 522.1 & 23.4 & 319.6 & 378.8 & 266.4 & 215.3 & 34.7 & 2.3 & $1,773.5$ & 7.84 \\
\hline & 通風設備 & 6.3 & $1,604.4$ & 6.5 & 749.3 & 259.9 & 514.3 & 101.9 & 22.1 & 0.9 & $3,265.6$ & 14.43 \\
\hline & |排水処理設備 & 8.6 & 575.0 & 15.7 & 281.4 & $\Delta 93.6$ & 274.4 & 173.5 & 28.5 & 1.7 & $1,265.1$ & 5.59 \\
\hline & 余熱利用設備 & 1.4 & 125.4 & 8.2 & 52.4 & $\Delta 28.2$ & 74.2 & 59.2 & 11.3 & 0.5 & 304.3 & 1.34 \\
\hline & 電気設備 & 6.6 & 270.1 & 42.9 & 159.0 & $\Delta 29.4$ & 200.9 & 250.8 & 40.2 & 2.5 & 943.6 & 4.17 \\
\hline & 計装設備 & 7.1 & 108.8 & 24.1 & 78.2 & 0.7 & 121.8 & 253.2 & 39.7 & 2.6 & 636.2 & 2.81 \\
\hline & 雑装置 & 1.3 & 96.1] & 6.0 & 39.2 & $\Delta 22.3$ & 60.4 & 56.1 & 9.9 & 0.5 & 247.2 & 1.09 \\
\hline \multirow{2}{*}{\multicolumn{2}{|c|}{ 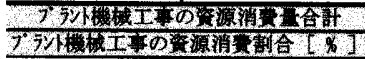 }} & 991 & 7.738 & 2835 & $4,434.1$ & $2,64.51$ & 3861.7 & 30128 & 6963 & 299 & 20683 & 20000 \\
\hline & & 0.4 & 34.3 & 13 & 19.6 & 11.7 & 171 & 13.3 & 2.2 & 0.1 & & 1000 \\
\hline
\end{tabular}

\begin{tabular}{|c|c|c|c|c|c|c|c|c|c|c|c|c|}
\hline (4)共通仮設等工 & 共通仮設 & 4.7 & 34.1 & 1.4 & 99.1 & 642.4 & 41.0 & 48.1 & 12.4 & 0.6 & 883.8 & 57.62 \\
\hline & 間接費 & 6.2 & 27.8 & 1.7 & 42.2 & 20.4 & 296.5 & 196.0 & 56.5 & 2.8 & 650.1 & 42.38 \\
\hline 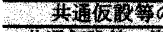 & 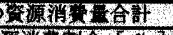 & 109 & 619 & 3.1 & 141.3 & 6628 & 337.5 & 2491 & 689 & 38 & 153399 & 70000 \\
\hline 通作整等 & 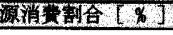 & 0.7 & 8.0 & 02 & 92 & 43.2 & 22.0 & 159 & 45. & 02 & & 1600 \\
\hline
\end{tabular}


表 6 建設エ事に関わる理境負荷

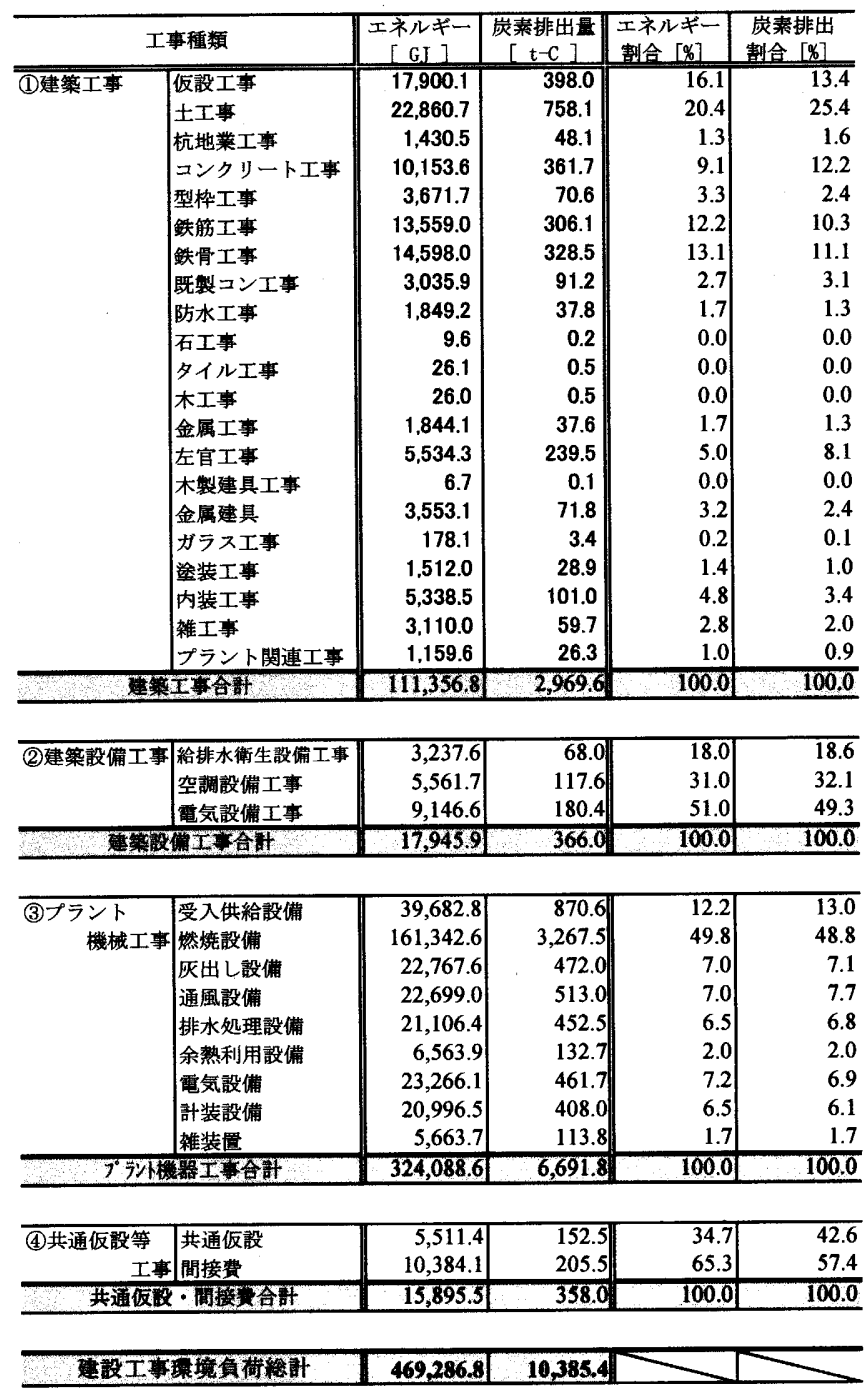
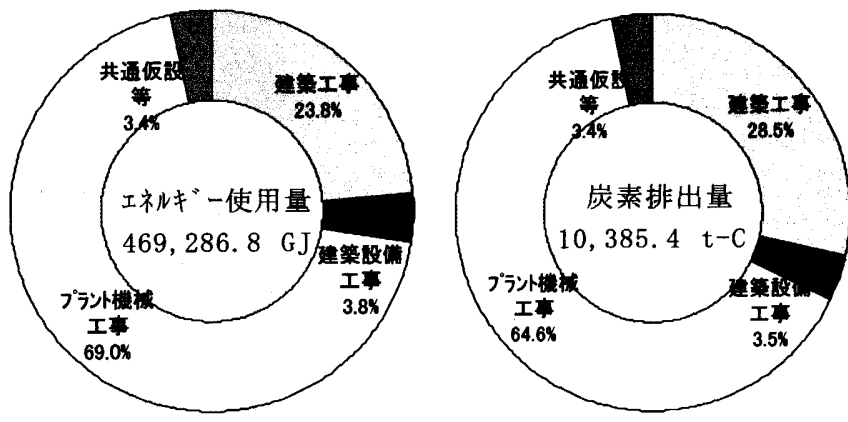

图 4 建設エ事別の㻴境負荷割合

成する主要な受入供給設備、焼却設備、灰出し設備、通風設 備、排水処理設備、余熱利用設備、電気設備、計装設備、雑装 置の 9 設備に分類して表 6 に示した。表 6 中のハッチング部分 は、建築工事、建築設備工事、プラント機械工事、共通仮設 工事それぞれのエネルギー使用量と炭素排出量の合計值を示 した。また、最下段に廃棄物焼却施設の建設工事に由来する エネルギー使用量と炭素排出量の総量を示した。建設工事に 関連して発生する環境負荷はエネルギー使用量が $469,286.8 \mathrm{GJ}$ 、炭素排出量が $10,385.4 \mathrm{t}$-C である。単位床面積 当りではエネルギー使用量が $42.7 \mathrm{G} \mathrm{J} / \mathrm{m}^{2}$ 、炭素排出量が $0.9 \mathrm{t}$ -
$\mathrm{C} / \mathrm{m}^{2}$ である。単位床面積当りの環境負荷は、環境負荷の総量 を延べ床面積 $\left(11 ， 000 \mathrm{~m}^{2}\right)$ で除して求めた。なお、建設工事 の工事種類別の環境負荷の割合を図 4 に示した。エネルギー 使用量の内訳は次の通りである。建筑工事のエネルギー使用 割合は $23.8 \%$ 、建築設備工事は $3.8 \%$ 、プラント機械工事は $69.0 \%$ 、共通仮設・経費は $3.4 \%$ である。また、炭素排出量に ついては、建築工事の炭素排出割合は $28.5 \%$ 、建築設備工事 は $3.5 \%$ 、プラント機械工事は $64.6 \%$ 、共通仮設・経費は $3.4 \%$ である。工事種類別の環境負荷はエネルギー使用量も炭素排 出量もプラント機器工事、建築工事、建築設備工事、共通仮 設・経費の順に多い。プラント機械工事の環境負荷が工事の 全体に占める割合は65〜70\%であり、施設の建設に由来する 環境負荷への影響度は最も大きい。次に、廃棄物焼却施設建 設に関連する環境負荷の大きさを相対的に評価するために、 オフィスビル建設工事の環境負荷との比較を行なった。18) オ フィスビルの単位床面積あたりの環境負荷はそれぞれエネル ギー使用量は $9.0 \mathrm{G} \mathrm{J} / \mathrm{m}^{2}$ であり、炭素排出量は $0.2 \mathrm{t}-\mathrm{c} / \mathrm{m}^{2}$ であ る。廃棄物焼却施設建設工事に由来する単位床面積 $\left(1 \mathrm{~m}^{2}\right)$ 当 りのエネルギー使用量はオフィスビルの 4.7 倍であり、炭素排 出量は 4.5 倍である。

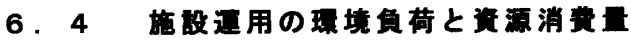

廃棄物焼却処理施設の運営において、1 年間に使用された資 材に由来する環境負荷を算出した。算出手法は、「 6.2 建設 工事の資源消費量」、 6 ．3 建設工事の環境負荷」と同様の手

\section{表 7 部設更用に関わる摆填負荷}

\begin{tabular}{|c|c|c|c|c|c|}
\hline \multicolumn{4}{|c|}{ 運用资材 } & \multirow{2}{*}{$\begin{array}{c}\text { エネルギー } \\
{[\mathrm{GJ} / \text { 年 }]}\end{array}$} & \multirow{2}{*}{$\begin{array}{l}\text { 炭素排出量 } \\
{[\mathrm{t}-\mathrm{C} / \text { 年 }]}\end{array}$} \\
\hline & 资材名 & 数 量 & 単位 & & \\
\hline \multirow{20}{*}{ 投入資材量 } & 部品・工具 & $\overline{-}$ & & $1,919.1$ & $\overline{40.8}$ \\
\hline & 消石灰 & 935 & $\mathrm{t}$ & $8,055.9$ & 161.5 \\
\hline & 反匛助剂 & 228 & $\mathrm{t}$ & $2,953.2$ & 59.2 \\
\hline & セメント & 226 & t & 702.8 & 32.1 \\
\hline & キレート骫 & 92 & $\mathrm{t}$ & $3,688.5$ & 76.5 \\
\hline & アンモニア水 $(25 \%)$ & 177 & $\mathbf{t}$ & $7,840.1$ & 138.3 \\
\hline & 塩酸 $(35 \%)$ & 22 & $\mathbf{t}$ & 72.4 & 1.5 \\
\hline & 苛性ソーダ $(24 \%)$ & 32 & $t$ & 154.0 & 3.1 \\
\hline & 塩化第二鉄 (37\%) & 5 & $\mathrm{t}$ & 18.8 & 0.4 \\
\hline & その他薬剤 & - & & $1,175.8$ & 23.4 \\
\hline & 事務·安全用品 & - & & 123.8 & 2.4 \\
\hline & 油脂 & - & & 37.1 & 0.7 \\
\hline & 軽油 & 1,101 & $\boldsymbol{e}$ & 4.5 & 0.8 \\
\hline & カソリン & 492 & $\boldsymbol{b}$ & 19.4 & 0.3 \\
\hline & $\overline{\text { ガス }}$ & 21,685 & $\mathrm{~m}^{3}$ & 847.0 & 11.9 \\
\hline & 水道 & 50,614 & $\mathrm{~m}^{3}$ & $1,592.4$ & 34.3 \\
\hline & 電気 & 258,252 & $\mathbf{k W h}$ & $1,813.0$ & 34.1 \\
\hline & 修緈 (炬内嘼火物) & - & & $3,715.8$ & 75.4 \\
\hline & 原材料 (配管類) & - & & 11.2 & 0.2 \\
\hline & 備品購入 (除應装置 & - & & 70.0 & 1.4 \\
\hline 投入这材 & 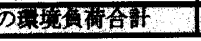 & & & 34.814 .8 & 6983 \\
\hline
\end{tabular}

\begin{tabular}{|c|c|c|c|c|}
\hline 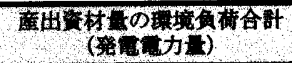 & $13,070,516$ & kwh & $\triangle 91,755,0$ & $\Delta 1,7253$ \\
\hline
\end{tabular}

表 8 施設荤用に関わる资源

\begin{tabular}{|c|c|c|c|c|c|c|c|c|c|c|}
\hline \multirow{2}{*}{$\begin{array}{l}\text { 资源種類 } \\
\text { 资源の } \\
\text { 投入産风 }\end{array}$} & \multicolumn{9}{|c|}{ 資源消費量 [ $\mathrm{t} /$ 年 ] } & \multirow[b]{2}{*}{$\begin{array}{l}\text { 合 計 } \\
{[t / \text { 年 }]}\end{array}$} \\
\hline & 木材 & 鉄鋼石 & $\begin{array}{l}\text { 銅 } \\
P N N^{\prime}\end{array}$ & 石灰石 & 砂利等 & 石 炭 & 原 油 & $\begin{array}{l}\text { 天然 } \\
\text { 为 }\end{array}$ & $\mid$ & \\
\hline 投入量 & 2.2 & 114.6 & 6.4 & 615.5 & 87.4 & 343.4 & 371.2 & 82.3 & 20.7 & $1,643.7$ \\
\hline 産出量 & $\Delta 2.2$ & $\Delta 12.7$ & $\Delta 0.1$ & $\Delta 17.1$ & $\Delta 29.7$ & A37.7 & $\Delta 397.8$ & A 549.9 & $\Delta \mathbf{1 8 . 0}$ & $\Delta 1,965.2$ \\
\hline 드. & 0.0 & 1019 & 63 & 598.4 & 57.7 & 55943 & (126.6 & N67.6 & 2.7 & 23215 \\
\hline
\end{tabular}


法を用いた。算出した環境負荷を表 7 に示し、資源消費量を 表 8 に示した。表 8 に示した資源消費量は表 7 に示した運用 資材や電力・ガス等のエネルギーに由来する資源の消費量を 示している。施設の運用時に発電した電力については、産出 量として示し、マイナス（ム）で表示した。環境負荷と資源 消費量は運用のために投入された資材と運用の結果副産物と して産出されるものに分けて示した。なお、廃棄物の焼却時 に廃菓物から直接排出される炭素量は運用に由来する炭素排 出量には算入していない。廃棄物の焼却処理を 1 年間実施す る為には、1，643.7t/年の資源が使用される(表 8 )。また、施 設運用時に使用される資材に起因するエネルギー使用量は、 $34,814.8 \mathrm{GJ} /$ 年、炭素排出量は $698.3 \mathrm{C}-\mathrm{t} /$ 年である（表 7 ）。環 境負荷の算定を行なった施設は焼却排熱を利用した発電を行 なっており、廃棄物焼却之同時に $91,755.0 \mathrm{GJ} /$ 年のエネルギー （電力）を生み出し、炭素排出量 $1,725.3 \mathrm{t}-\mathrm{C} /$ 年と資源消費量 $1,965.2 \mathrm{t} /$ 年を削減している。従って、施設の運用に伴って投 入される資源に副産物として産出される資源等による差引き を考慮すると正味のエネルギ一使用量、炭素排出量、資源消

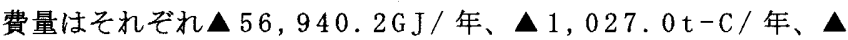
$321.5 \mathrm{t}-\mathrm{C} /$ 年である(表 7 )。表 7 と表 8 中のマイナス（山）の 数字は、廃棄物処理によって副産物が生成されることを表し ている。表 7 と表 8 中では排熱発電による電力やこの発電の 為に電力会社の発電を補完するために削減される環境負荷や 資源などを副産物と考え、マイナス（山）表示とした。つま り、施設を運用して排熱発電を行なうことによって、施設の 建設に投入されたエネルギ一、排出された炭素、消費された 資源を回収していると解釈することができる。

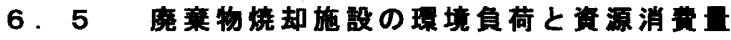

廃棄物焼却処理施設について建設と運用に由来する環境負 荷と資源消費量を統合して考察を行なった。算出手法は「 6 . 2 建設工事の資源消費量」、6.3 建設工事の環境負荷」、 「 6.4 施設運用の環境負荷と資源消費量」で求めた計算值を 施設の延べ床面積 $\left(11 ， 000 \mathrm{~m}^{2}\right)$ で除して求めた。なお、炭素 排出量の算定に関しては、廃棄物の焼却時に廃棄物から直接 排出される炭素量は運用に由来する炭素量には算入していな い。以上の計算結果をもとに施設の運用期間を 8 年として計算 を行い、計算結果を表 9 に示した。運用期間を 8 年とした理由 は、廃棄物焼却施設は運用開始から 10 年程度を経過すると設 備の劣化が顕著になると同時に、部品の入手が困難となる21)。 従って、運用開始から 10 年以前に一定規模の単体設備の更新 が行なわれていると考えられるためである。表 9 には環境負 荷と資源消費量の内訳を施設建設過程、施設運用過程及び両 者の合計值で示した。また、施設運用過程については運用時 に使用する資材と排熱発電による電力量に分けて示した。エ

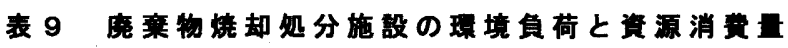

\begin{tabular}{|c|c|c|c|c|}
\hline \multicolumn{2}{|c|}{$\begin{array}{c}\text { 環境負荷と資源 } \\
\text { 排出時期等 }\end{array}$} & \begin{tabular}{|c|} 
エネルギー \\
使用量 $\left[\mathrm{GJ} / \mathrm{m}^{2}\right]$
\end{tabular} & $\begin{array}{l}\text { 炭素排出量 } \\
{\left[\mathrm{t}-\mathrm{C} / \mathrm{m}^{2}\right]}\end{array}$ & $\begin{array}{c}\text { 資源消費量 } \\
{\left[\mathrm{t} / \mathrm{m}^{2}\right]}\end{array}$ \\
\hline 施設建設 & 建設資材 & 42.7 & 0.9 & 4.4 \\
\hline & & 25.3 & 0.5 & 1.2 \\
\hline & 排熱発電 & $\Delta 66.7$ & $\Delta 1.3$ & $\Delta 1.4$ \\
\hline 環境負荷 & 資源量合計 & 1.3 & 0.1 & 4.2 \\
\hline
\end{tabular}

ネルギー使用量、炭素排出量、資源消費量はそれぞれ $1.3 \mathrm{G} \mathrm{J} /$ $\mathrm{m}^{2} 、 0.1 \mathrm{t}-\mathrm{C} / \mathrm{m}^{2} 、 4.2 \mathrm{t} / \mathrm{m}^{2}$ である。施設の運用期間が 8 年時点 では、建設工事でのエネルギー使用量と炭素排出量を排熱発 電によるエネルギー削減量と炭素排出の削減量が上回ってい る。また、施設の運用過程では使用した資材に由来するエネ ルギー使用量、炭素排出量、資源消費量よりも排熱発電によ るエネルギー削減量、炭素排出の削減量、資源の削減量の方 が上回り、それぞれ 2.6 倍、 2.6 倍、1.2 倍となる。また、異 なる規模の廃棄物焼却処理施設については廃棄物焼却に由来 するエネルギー使用量、炭素排出量、資源使用量を施設の単 位床面積又は、施設の単位処理能力（1t/日）当りの量で等価 に比較することができると考えられることから廃棄物焼却処 理能力 $(360 \mathrm{t} /$ 日) で環境負荷と資源使用量を除した単位処理 能力（1 t/ 日）あたりの環境負荷と資源使用量についても併せ て計算した。単位処理能力 $(1 \mathrm{t} /$ 日) 当りのエネルギー使用量、 炭素排出量、資源使用量はそれぞれ $38.3 \mathrm{GJ} /(\mathrm{t} /$ 日) 、6.0 $\mathrm{t}-\mathrm{C} /$ (t/日)、128.7t/( t/ 日)である。

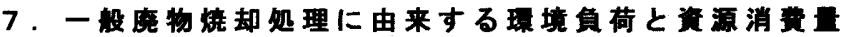

前出の「 6.3 建設工事の環境負荷」と「 6.4 施設運 用の環境負荷と資源消費量」のエネルギー使用量、炭素排出 量、資源消費量の計算值をもとに 1 トンの一般廃棄物を焼却 処理するためのエネルギー使用量、炭素排出量、資源消費量 を算出した。計算方法は、廃棄物焼却施設の建設工事と施設 運用時の使用資材や排熱発電の電力量に起因する総エネル ギ一量、総炭素排出量、総資源消費量を焼却処理した一般廃 粪物の総量で除して求めた。計算条件は表 10 に示し、㛙却処 理を行なった廃棄物 $1 \mathrm{t}$ 当りの環境負荷と資源消費量の計算值 を表 11 に示した。1トンの一般廃棄物を焼却するためには、 エネルギー使用量は $36.1 \mathrm{MJ} / \mathrm{t}$ 、炭素排出量は $5.7 \mathrm{~kg}-\mathrm{C} / \mathrm{t}$ 、資源 消費量は $121.9 \mathrm{~kg} / \mathrm{t}$ である。施設の運用期閒が 8 年時点では、 施設建設時のエネルギー使用量と炭素排出量を排熱発電によ るエネルギー削減量と炭素排出の削減量が上回る。施設建設 時と運用時の資材に由来するエネルギー使用量は合計で $1,966.2 \mathrm{M} \mathrm{J} / \mathrm{t}$ 、排熱発電によって削隇されるエネルギー削減量 は $1 ， 930$. $1 \mathrm{M} \mathrm{J} / \mathrm{t}$ であり、正味のエネルギー使用量は $1,966.2 \mathrm{MJ} / \mathrm{t}$ の約 $2 \%$ となる $36.1 \mathrm{MJ} / \mathrm{t}$ に削減される。炭素排出 量は建設と運用時の資材に由来する量は合計して $42.0 \mathrm{~kg}-\mathrm{C} / \mathrm{t}$ 、 排熱発電によって削減される炭素排出量は $36.3 \mathrm{~kg}-\mathrm{C} / \mathrm{t}$ 、正味 の炭素排出量は $42.0 \mathrm{~kg}-\mathrm{C} / \mathrm{t}$ の $14 \%$ となる $5.7 \mathrm{~kg}-\mathrm{C} / \mathrm{t}$ に削減さ れる。資源消費量は建設と運用時の資材に由来する量は合計 して $163.2 \mathrm{~kg} / \mathrm{t}$ 、排熱発電によって削減される炭素排出量は

\section{表 10 計算の条件}

\begin{tabular}{ccc}
\hline 施設運用期間 & $:$ & 8 年 \\
\hline 廃棄物焼却処分量 : & $47,540 \mathrm{t} /$ 年 \\
\hline
\end{tabular}

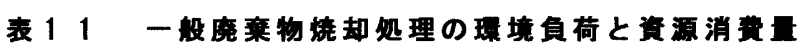

\begin{tabular}{|c|c|c|c|c|}
\hline \multicolumn{2}{|c|}{$\begin{array}{c}\text { 環境負荷と出資源 } \\
\text { 時期等 }\end{array}$} & $\begin{array}{c}\text { エネルギー } \\
\text { 使用量 }[\mathrm{MJ} / \mathrm{t}] \\
\end{array}$ & $\begin{array}{c}\text { 炭素排出量 } \\
{[\mathrm{kg}-\mathrm{C} / \mathrm{t}]}\end{array}$ & $\begin{array}{c}\text { 資源消費量 } \\
{[\mathrm{kg} / \mathrm{t}]}\end{array}$ \\
\hline 施設建設 & 建設資材 & $1,233.9$ & 27.3 & 128.6 \\
\hline 施設運用 & $\begin{array}{l}\text { 運用㕠材 } \\
\text { 排熱発電 }\end{array}$ & $\begin{array}{r}732.3 \\
\triangle 1,930.1\end{array}$ & $\begin{array}{r}14.7 \\
\wedge \quad 36.3 \\
\end{array}$ & $\begin{array}{r}34.6 \\
\Delta 41.3 \\
\end{array}$ \\
\hline 環境負荷 & 資源量合計 & 36.1 & 5.7 & 121.9 \\
\hline
\end{tabular}


$41.3 \mathrm{~kg} / \mathrm{t}$ 、正味の炭素排出量は $163.2 \mathrm{~kg} / \mathrm{t}$ の $75 \%$ となる $121.9 \mathrm{~kg} / \mathrm{t}$ に削減される。以上のことから、廃棄物の焼却処理 では、排熱発電を積極的に行ない施設の長期間運用すること によって1トンの廃棄物の焼却処理に要するエネルギー使用

量、炭素排出量、資源消費量を削減することができる。

\section{8.まとめ}

廃棄物焼却処理施設の建設と運用に関するエネルギー使用 量と炭素排出量と資源消費量の算出を行い、以下の結論を得 た。

（1）廃棄物焼却処理施設の建設工事に関連する環境負荷はエ ネルギー使用量が $469,286.8 \mathrm{GJ}$ 、炭素排出量は $10,385.4 \mathrm{t}-\mathrm{C}$ で あり、資源消費量は $48,906.2 \mathrm{t}$ である。

（2）建設工事に関連する単位床面積当りの総環境負荷はエネ ルギー使用量が $42.7 \mathrm{G} \mathrm{J} / \mathrm{m}^{2}$ 、炭素排出量は $0.9 \mathrm{t}-\mathrm{C} / \mathrm{m}^{2}$ であり、 資源消費量は $4.4 \mathrm{t} / \mathrm{m}^{2}$ である。オフィスビルの環境負荷と比較 するとエネルギー使用量と炭素排出量はそれぞれ 4.7 倍、 4.5 倍である。また、建設工事過程と 8 年間の運用過程をあわせた 単位床面積当りの環境負荷はエネルギー使用量が $1.3 \mathrm{G} \mathrm{J} / \mathrm{m}^{2}$ 、 炭素排出量は $0.1 \mathrm{t}-\mathrm{C} / \mathrm{m}^{2}$ であり、資源消費量は $4.2 \mathrm{t} / \mathrm{m}^{2}$ である。 （3）建設工事に関連するエネルギー使用量を建築工事、建築 設備工事、プラント機器工事、共通仮設・経費に分類すると、 総エネルギー使用量に占める割合はそれぞれ $23.8 \% 、 3.8 \%$ 、 $69.0 \% 、 3.4 \%$ である。エネルギー使用量が多い工事種類の上 位 3 項目はプラント機械工事の燃焼設備工事、受入供給設備 工事、建築工事の土工事である。

(4) 建設工事に関連する炭素排出量は建築工事、建築設備工 事、プラント機器工事、共通仮設・経費に分類すると、炭素 排出量に占める割合はそれぞれ $28.5 \% 、 3.5 \% 、 64.6 \% 、 3.4$ $\%$ である。炭素排出量が多い工事種類の上位 3 項目はプラン 卜機械工事の燃焼設備工事、受入供給設備工事、建築工事の 土工事である。

（5）建設工事において消費される資源の割合は、鉄鉱石 28.3 $\%$ 、石灰石 $23.5 \%$ 、砂利等 $23.4 \%$ である。資源消費量が多い 工事項目の上位 3 項目は建築工事のコンクリートエ事、プラ ント機器工事の燃焼設備工事、受入供給設備工事である。

（6）廃棄物焼却処理施設を 8 年間運用した場合を想定し、廃 棄物 1 トンを焼却処理するためのエネルギー使用量、炭素排 出量、資源消費量を算出した結果、それぞれ $36.1 \mathrm{MJ} / \mathrm{t} 、 5.7 \mathrm{~kg}-$ $\mathrm{C} / \mathrm{t} 、 121.9 \mathrm{~kg} / \mathrm{t}$ である。

\section{考文献}

）林英明他：地域配管の建設によるエネルギー消費量と二酸化炭素排 出量, 日本建筑学会計画系論文集 No. 521, pp81-87, 1999, 7

2) 井村秀文 : 建設の LCA，オーム社，平成 13 年 6 月

3）鈴木道哉他：住宅建設によるエネルギー消費量と二酸化炭素排出量, 産業連関表による建物の評価（その 3 ），日本建築学会計画系論文集 No. 463 , pp 75-82, 1994. 9

4）鈴木道哉他：事務所ビルの建設・運用に関するエネルギー消費量と二 酸化炭素排出量，産業連関表による建物の評価（その 4)，日本建筑 学会計画系論文集 No. 476, pp37-43, 1995.10

5）吉田直裕：N ビルにおけるライフサイクルアセスメント実施例，日本 建築学会大会学術講演梗概集集,pp1009-1010,2001.9
6）白井 裕子：埼玉県における処理人口の規模からみたごみ焼却施設の 整備実態とその問題点に関する調查, 日本建築学会計画系論文集 No. $563, \mathrm{pp} 53-69,2003.1$

7）永田勝也：廃棄物焼却発電システムの LCA 評価，第 9 回廃棄物学会 研究発表会講演論文集, pp87-90,1998

8） 木原勇信：生活系一般廃㐮物に係わる環境負荷の把握，第 17 回工 ネルギーシステム・経済・環境コンファレンス講演論文集 , pp 685690,2001

9）厚生省生活衛生局水道環境部環境整備課長通知：ごみ処理の広域化 について，1997

10）岡 建雄：建設に関わる資源消費量の算出, 建築設備士, 1993.3

11）吉田公夫他：石炭火力発電所建物建設に伴う環境負荷及びフライアッ シュセメント利用による環境負荷低減効果の評価，産業連関表によ る建物の評価（その9） 日本建築学会計画系論文集 No.544,pp79$84,2001.6$

12）総務庁：1995 年産業連関表 計数編 (1)，(2)，1999.3，（財）全国統 計協会連合会

13） A 市廃棄物焼却処分場建設工事資料

14）日立造船（株）：有価証券報告書，日立造船（株），1995

15）横山計三：1995 年表による資源消費原単位，産業連関表による建物の 評価（その 10)，日本建築学会計画系論文集 No. 568,pp1-7, 2003.6

16）（財）建設物価調査会：建設工事標準步挂（平成 7 年度版）

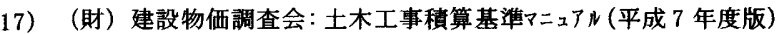

18）（社）日本建設機械化協会：建設機械等損料算定表（平成 7 年度版）

19）（社）公共建築協会：建設省建築工事積算基準（平成 7 年度版）

20）横山謙司：1995 年表によるエネルギー消費量と炭素排出量の原単位。 産業連関表による建物の評価（その 8 ），日本建筑学会計画系論文集 No. 531 , pp $75-80,2000.5$

21）廃棄物学会 : 廃棄物ヘンドブック,P273，1997.4, オーム社

\section{注 航}

1）山留め工事の中の工法の一つである。 2 連又は 3 連の多軸混練オ一 ガー機で地盤を掘削し、その先端より、セメントスラリーを噴出し て掘削と同時に土とセメントの混練を行なう。次に、セメントと土 を混練りしと同時に削孔した部分に H 型鎆や I 型鋼を挿入する。セ メントが硬化後には、中心に鋼材があり、鋼材の周囲が土とセメン トで硬化された連続壁が形成され、山留め壁となる。図 5 にソイル セメント連続壁の平面図を示す。

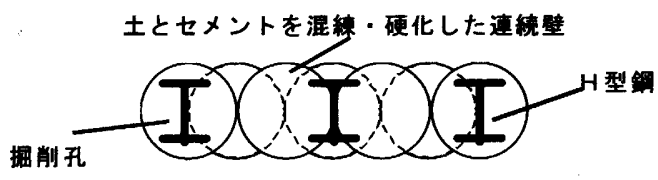

圑 5 